\title{
New records of feather mites (Acariformes: Analgoidea, Pterolichoidea) in Piracicaba, SP, Brazil
}

\author{
Fabio A. Hernandes ${ }^{1 \pm=(0)}$, Carlos H.W. Flechtmann ${ }^{2}$
}

${ }^{1}$ Departamento de Ecologia e Zoologia, CCB/ECZ, Trindade, Universidade Federal de Santa Catarina, 88040-970, Florianópolis, Santa Catarina, Brazil, CNPq-Brazil Researcher (304479/2019-5). '2Departamento de Entomologia e Acarologia, Escola Superior de Agricultura "Luiz de Queiroz", Universidade de São Paulo, 13418-900, Piracicaba, São Paulo, Brazil.

莑=Corresponding author: abakashi@gmail.com

Edited by: Peterson R. Demite

Received: February 20, 2020. Accepted: March 11, 2020. Published: May 29, 2020.

Abstract. Seven species and four undetermined feather mites are reported from various birds in Piracicaba, Brazil: Dermoglyphus elongatus Mégnin, 1877 (Dermoglyphidae) ex Gallus gallus domesticus (Linnaeus, 1758) "chicken" (Phasianidae), Mesosathes tetrasetosus (Novaes, 1953) (Crypturoptidae) and Neumannella astacus Dabert \& Skoracki, 2004 (Dermoglyphidae) ex Crypturellus tataupa (Temminck, 1815) "tataupa tinamou" (Tinamidae), Piciformobia ani (Černý, 1915) (Gabuciniidae) ex Crotophaga ani Linnaeus, 1758 "smooth-billed ani" (Cuculidae), Piciformobia guirae Alzuet, Cicchino \& Abrahamovich, 1988 (Gabuciniidae) ex Guira guira (Gmelin, 1788) "guira cuckoo" (Cuculidae), Proctophyllodes thraupis Atyeo \& Braasch, 1966 (Proctophyllodidae) ex Thraupis sayaca (Linnaeus, 1766) "sayaca tanager" (Thraupidae), Proctophyllodes troncatus Robin, 1877 ex Passer domesticus (Linnaeus, 1758) "house sparrow" (Passeridae); and undetermined species of the genera: Amerodectes sp. (Proctophyllodidae), Mesalgoides sp. (Psoroptoididae), and Trouessartia sp. (Trouessartiidae) ex Arundinicola leucocephala (Linnaeus, 1764) "white-headed marsh tyrant" (Tyrannidae), and Analges sp. (Analgidae) ex Euphonia chlorotica (Linnaeus, 1766) "purple-throated euphonia" (Fringillidae). Four of them are recorded for the first time in Brazil: D. elongatus, Pi. ani, Pr. thraupis, and Pr. troncatus.

Keywords: Acari, Astigmata, feather mites, new records, plumicolous mites.

Despite recent advancements in the knowledge about feather mites of Brazil (e.g. Valim et al. 2011; Pedroso \& Hernandes 2016; Hernandes 2019), the country still has several unknown feather mite associations. The aim of this work is to report feather mites from birds found in Piracicaba, São Paulo State, Brazil.

The examined feathers were obtained from dead birds either after collision with glass windows or found dead in rural areas. Feather mites were collected in the laboratory by CHWF under a dissecting microscope, from the following body regions: remiges (large wing feathers), rectrices (large tail feathers), contour (small outline wing feathers), calamus or quill (basal portion of feather shaft inserted into the follicle in the skin). Mites were mounted in glass slides using Hoyer's medium. Voucher specimens are deposited at the mite collection of the Department of Ecology and Zoology of the Universidade Federal de Santa Catarina (ECZ - UFSC).

Seven feather mite species and four undetermined species (Figs. $1 \mathrm{~A}-\mathrm{T}$ ) were recorded from various birds. Four species are recorded for the first time in Brazil.

Dermoglyphus elongatus Mégnin, 1877 (Analgoidea: Dermoglyphidae) (Fig. 1A), 1 female ex Gallus gallus domesticus (Linnaeus, 1758) "chicken" (Galliformes: Phasianidae), 07 November 1979, Piracicaba, São Paulo, Brazil, quills.

Remarks: this quill mite was described from G. gallus (type host) and small passerines such as Serinus canaria (Linnaeus, 1758) (Passeriformes: Fringillidae) and Amandava spp. (Passeriformes: Estrildidae). Gaud (1974) demonstrated that the mite from passerines constitutes a distinct species, D. passerinus Gaud, 1974. To our knowledge, this is the first record of the species in Brazil.
Mesosathes tetrasetosus (Novaes, 1953) (Pterolichoidea: Crypturoptidae) (Figs. 1B-E), 1 male, 5 females, ex Crypturellus tataupa (Temminck, 1815) "tataupa tinamou" (Tinamiformes: Tinamidae), 10 August 1975, Piracicaba, São Paulo, Brazil, remiges.

Remarks: this species was described from C. tataupa in Espírito Santo, Brazil (Novaes 1953) and was later reported from the same host species in Argentina, Brazil, and Paraguay, and also on C. parvirostris (Wagler, 1827) in Argentina and Brazil (Gaud et al. 1972). The type series, originally housed at the Museu Nacional, Rio de Janeiro, were probably destroyed in the fire of 2018.

Neumannella astacus Dabert \& Skoracki, 2004 (Analgoidea: Dermoglyphidae) (Fig. 1F), 2 females, 1 larva, ex Crypturellus tataupa (Temminck, 1815) "tataupa tinamou" (Tinamiformes: Tinamidae), 10 August 1975, Piracicaba, São Paulo, Brazil, calamus.

Remarks: species recorded from the type host, described from Brazil (Dabert \& Skoracki 2004); the genus includes currently seven species (Hernandes et al. 2017), all of them are syringicoles (live inside quills) associated with the Neotropical tinamous (Tinamiformes).

Piciformobia ani (Černý, 1975) (Pterolichoidea: Gabuciniidae) (Figs. 1G-H), 12 males, 14 females, 1 nymph, ex Crotophaga ani Linnaeus, 1758 "smooth-billed ani" (Cuculiformes: Cuculidae), 23 August 1975, Piracicaba, São Paulo, Brazil, remiges.

Remarks: originally described from $C$. ani in Suriname, this species was later reported in Argentina on the type host, and also on Crotophaga sulcirostris Swainson, 1827 and C. major Gmelin, 1788 (Alzuet et al. 1988). This species is recorded for the first time in Brazil. Although superficially quite similar to Piciformobia guirae Alzuet, Cicchino \& Abrahamovich, 1988, this species has setae $c G$ on genu I 
about twice longer, approximately the length of genu + tibia combined, while in $P$. guirae this seta is as long as - or only slightly longer than genu I.

Piciformobia guirae Alzuet, Cicchino \& Abrahamovich, 1988 (Pterolichoidea: Gabuciniidae) (Figs. 1l-J), 14 males, 14 females, 3 nymphs, ex Guira guira (Gmelin, 1788) "guira cuckoo" (Cuculiformes: Cuculidae), 16 August 1975, Piracicaba, São Paulo, Brazil, remiges.

Remarks: This species was described from G. guira in Argentina, and also recorded in Piracicaba, Brazil (Alzuet et al. 1988). Recently, a second species of Piciformobia was described from the same host in Brazil (Hernandes 2020).

Proctophyllodes thraupis Atyeo \& Braasch, 1966 (Analgoidea: Proctophyllodidae) (Figs. $1 \mathrm{~K}-\mathrm{L}$ ), 11 males, 14 females, 2 nymphs, ex Thraupis sayaca (Linnaeus, 1766) "sayaca tanager" (Passeriformes: Thraupidae), 16 August 1975, Piracicaba, São Paulo, Brazil, remiges.

Remarks: this species was described from Thraupis abbas (Deppe, 1830) in Mexico, but also recorded on the following hosts: Chlorophanes spiza (Linnaeus, 1758) (Thraupidae) in Honduras and Mexico, Sporophila corvina ophthalmica (Sclater, 1860) (Thraupidae) in Mexico, Euphonia affinis (Lesson, 1842) (=Tanagra affinis) (Fringillidae) in Mexico; Euphonia hirundinacea Bonaparte, 1838 (=Tanagra lauta Bangs \& Penard, 1919) in Honduras; Euphonia musica (Gmelin, 1789) (=Tanagra musica) in Mexico. It is herein reported for the first time in Brazil.

Proctophyllodes troncatus Robin, 1877 (Analgoidea: Proctophyllodidae) (Figs. 1M-N), 2 males, 6 females, 6 nymphs, ex Passer domesticus (Linnaeus, 1758) "house sparrow" (Passeriformes: Passeridae), 07 August 1975, Piracicaba, São Paulo, Brazil, remiges and rectrices.

Remarks: originally described from $P$. domesticus, this species constitutes one of the few examples of feather mites collected over a wide geographical range, following the widespread distribution of its primary host (Atyeo \& Braasch 1966; Mironov 2012). This species is reported for the first time in Brazil, and to our knowledge, for the first time in the Neotropical region.

\section{Undetermined species:}

Amerodectes sp. (Analgoidea: Proctophyllodidae) (Fig. 10), 1 male ex Arundinicola leucocephala (Linnaeus, 1764) "white-headed marsh tyrant" (Passeriformes: Tyrannidae), 31 August 1975, Piracicaba, São Paulo, Brazil, remiges.

Remarks: this represents an undescribed species.

Analges sp. (Analgoidea: Analgidae) (Figs. 1P-Q), 2 males, 3 females, 1 nymph, ex Euphonia chlorotica (Linnaeus, 1766) "purplethroated euphonia" (Passeriformes: Fringillidae), 12 September 1975, Piracicaba, São Paulo, Brazil, no further data.

Remarks: with approximately 64 described species mainly associated with passerines (Mironov 2019), a single species of this genus was described from Brazil (Pedroso \& Hernandes 2018).

Mesalgoides sp. (Analgoidea: Psoroptoididae) (Figs. 1R-S), 2 males and 1 female ex Arundinicola leucocephala (Linnaeus, 1764) "whiteheaded marsh tyrant" (Passeriformes: Tyrannidae), 31 August 1975, Piracicaba, São Paulo, Brazil, contour feathers.

Remarks: this represents an undescribed species.

Trouessartia sp. (Analgoidea: Trouessartiidae) (Fig. 1T), 1 female ex Arundinicola leucocephala (Linnaeus, 1764) "white-headed marsh tyrant" (Passeriformes: Tyrannidae), 31 August 1975, Piracicaba, São Paulo, Brazil, remiges.

Remarks: this represents an undescribed species. slided, and provisionally identified the mites. There is no conflict of interest between authors.

\section{Acknowledgements}

To the late professor Warren T. Atyeo (in memoriam) for his initial determination of the feather mites reported herein.

\section{References}

Alzuet, A.D.B.; Chicchino, A.C.; Abrahamovich, A.H. (1988) Consideraciones taxonómicas y relaciones hospedatórias de los géneros Coraciacarus Dubinin 1956, Piciformobia Gaud y Atyeo 1975 y Capitolichus Gaud y Atyeo 1975 (Acari, Astigmata, Gabuciniidae), com descripción de tres nuevas espécies. Revista de la Asociación de Ciencias Naturales del Litoral, 19(1): 49-67. doi: 10.14409/natura.v1i19.3550

Atyeo, W.T.; Braasch, N.L. (1966) The feather mite genus Proctophyllodes (Sarcoptiformes, Proctophyllodidae). Bulletin of the University of Nebraska State Museum, 5: 1-354.

Dabert, J.; Skoracki, M. (2004) Two new species of the genus Neumannella Trouessart, 1916 (Analgoidea, Dermoglyphidae) from the tataupa tinamou Crypturellus tataupa (Temminck, 1815) (Aves, Tinamiformes). Acta Parasitologica, 49(3): 237-245.

Gaud, J. (1974) Some new species of sarcoptiform feather mites (Analgidae and Dermoglyphidae) parasitic of European birds. Acarologia, 15(4): 727-758.

Gaud, J.; Atyeo, W.T.; Berla, H.F. (1972) Acariens Sarcoptiformes plumicoles parasites des tinamous. Acarologia, 14(3): 393-453.

Hernandes, F.A. (2019) Microspalax atlanticus sp. nov. (Acariformes: Alloptidae), the first feather mite from a procellariiform bird in Brazil (Aves: Procellariiformes). Systematic \& Applied Acarology, 24(3): 414-422. doi: 10.11158/saa.24.3.7

Hernandes, F.A. (2020) A review of the feather mite family Gabuciniidae Gaud \& Atyeo (Acariformes: Astigmata: Pterolichoidea) of Brazil, with descriptions of eleven new species. Zootaxa, 4747(1): 001053. doi: 10.11646/zootaxa.4747.1.1

Hernandes, F.A.; Bauchan, G.; Ochoa, R. (2017) New and little known feather mites (Acariformes: Astigmata) analyzed with Low Temperature Scanning Electron Microscopy. International Journal of Acarology, 43(7): 499-517. doi: 10.1080/01647954.2017.1367032

Mironov, S.V. (2012) New species of the feather mite genus Proctophyllodes Robin, 1877 (Acari: Analgoidea: Proctophyllodidae) from European passerines (Aves: Passeriformes), with an updated checklist of the genus. Acarina, 2020(2): 130-158.

Mironov, S.V. (2019) A new species of the feather mite genus Analges Nitzsch, 1818 (Acariformes: Analgidae) from the streaked spiderhunter Arachnothera magna (Passeriformes: Nectariniidae), with a renewed diagnosis and world checklist to the genus. Acarina, 27(1): 19-43

Novaes, F.C. (1953) A new species of "Neumaniella" from the "Tataupa tinamous" (Sarcoptiformes, Analgesidae). Revista Brasileira de Biologia, 13(2): 203-204.

Pedroso, L.G.A.; Hernandes, F.A. (2016) New records of feather mites (Acariformes: Astigmata) from nonpasserine birds (Aves) in Brazil. Checklist, 12(6): 1-25. doi: 10.15560/12.6.2000

Pedroso, L.G.A.; Hernandes, F.A. (2018) Two new feather mite species of the family Analgidae (Acariformes: Analgoidea) from the Rufous-collared Sparrow Zonotrichia capensis (Müller, 1776) (Passeriformes: Passerellidae). Zootaxa, 4461(2): 233-244 doi: 10.11646/zootaxa.4461.2.4

Valim, M.P.; Hernandes, F.A.; Proctor, H.C. (2011) Feather mites of Brazil (Acari: Astigmata: Analgoidea and Pterolichoidea). International Journal of Acarology, 37(4): 293-324. doi: 10.1080/01647954.2010.519719

\section{Authors' contributions}

FAH identified the mites and wrote the results; CHWF collected, 




Figure 1. Feather mites from birds in Piracicaba, Brazil: Dermoglyphus elongatus Mégnin, 1877, female (A); Mesosathes tetrasetosus (Novaes, 1953), male (B, C) and female (D, E); Neumannella astacus Dabert \& Skoracki, 2004, female (F); Piciformobia ani (Černý, 1915), male (G) and female (H); Piciformobia guirae Alzuet, Cicchino \& Abrahamovich, 1988, male (I) and female (J); Proctophyllodes thraupis Atyeo \& Braasch, 1966, male (K) and female (L); Proctophyllodes troncatus Robin, 1877, male (M) and female (N); Amerodectes sp., male (O); Analges sp., male (P) and female (Q); Mesalgoides sp., male (R) and female (S); Trouessartia sp., female (T). Scalebar: = A-B, D, F-J, P, T = 200 $\mu \mathrm{m} ; C, E, K-O, Q-S=100 \mu \mathrm{m}$. 